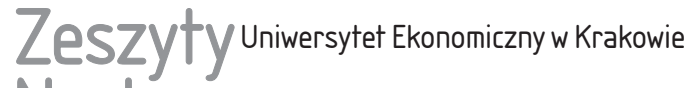 Naukowe
}

$8(944)$

ISSN 1898-6447

Zesz. Nauk. UEK, 2015; 8(944): 69-77 DOI: 10.15678/ZNUEK.2015.0944.0806

\author{
Joanna Krzyżak \\ Marek Motyka \\ Katedra Psychologii i Dydaktyki \\ Uniwersytet Ekonomiczny w Krakowie
}

\section{Kultura zaangażowania organizacyjnego a potrzeby psychospołeczne pracowników*}

\section{Streszczenie}

Z psychologicznego punktu widzenia u podstaw motywacji do działania leżą istotne potrzeby człowieka: biologiczne, ekonomiczne i psychospołeczne. Wraz z poprawą ogólnych warunków życia ta ostatnia grupa potrzeb nabiera coraz większego znaczenia, co sprawia, że w skutecznym motywowaniu pracowników rośnie znaczenie złożonych wzmocnień o psychospołecznym charakterze.

W artykule starano się zwrócić uwagę na często niedoceniany w praktyce zarządzania problem znaczenia wewnętrznej motywacji pracowników. Zwrócono uwagę szczególnie na rolę uwzględnienia w kulturze organizacyjnej firmy podstawowych potrzeb psychospołecznych pracowników, co jest zasadniczym czynnikiem budującym zaangażowanie organizacyjne.

Słowa kluczowe: zaangażowanie organizacyjne, kultura organizacyjna, potrzeby psychospołeczne, motywacja, zarządzanie.

* Artykuł powstał w ramach realizacji tematu badawczego finansowanego ze środków przyznanych Wydziałowi Ekonomii i Stosunków Międzynarodowych Uniwersytetu Ekonomicznego w Krakowie w ramach dotacji na utrzymanie potencjału badawczego. 


\section{Wprowadzenie}

W najbardziej ogólnym ujęciu przez kulturę organizacyjną należy rozumieć system podstawowych założeń funkcjonujących w środowisku społecznym danej organizacji, które wyznaczają zarówno panujący w niej klimat, jak i zasady postępowania. Szczególnymi elementami kultury organizacyjnej są należące do niej normy, wartości i przekonania, a także przyjęte rytuały, symbole i mity [Schein 1988, Kożusznik 2007]. Kultura organizacyjna ingeruje głęboko w zachowania pracownicze jako ważny aspekt działania całej organizacji, wymagający uwzględnienia, zwłaszcza kiedy chcemy zrozumieć i wyjaśnić występujące w niej zjawiska.

Kształtowanie kultury zaangażowania organizacyjnego można traktować jako działanie zmierzające do stworzenia optymalnego środowiska pracy, w którym pracownik nie tylko dobrze się czuje, ale też w sposób aktywny włącza się w realizowanie celów stawianych przez organizację. Aktywność ta określana bywa terminem „,zaangażowanie organizacyjne”. W ogólnym ujęciu, najbardziej trafne wydaje się definiowanie zaangażowania jako pozytywnego stanu motywacyjnego (o charakterze afektywno-poznawczym), na co zwraca uwagę wielu badaczy [Mastrangelo 2008, Bakker 2011, Chirkowska-Smolak 2012].

$\mathrm{Z}$ psychologicznego punktu widzenia u podstaw motywacji do jakiegokolwiek działania leżą istotne potrzeby człowieka: biologiczne, ekonomiczne i psychospołeczne. Warto zauważyć, że wraz z poprawą ogólnych warunków życia ta ostatnia grupa potrzeb nabiera coraz większego znaczenia, co sprawia, że w skutecznym motywowaniu pracowników rośnie znaczenie złożonych wzmocnień o psychospołecznym charakterze.

Należy w tym miejscu zaznaczyć, że o ile w przypadku podstawowych potrzeb biologicznych i ekonomicznych najważniejsza jest możliwość faktycznego ich zaspokojenia, to w przypadku potrzeb psychicznych, takich jak: kontakt emocjonalny, autonomia, szacunek, potrzeba sensu czy samorealizacji, liczy się nie tylko to, czy organizacja potrzeby te faktycznie zaspokaja, ale czy w ogóle je dostrzega i czy tworzy warunki sprzyjające ich realizacji w sposób odczuwalny dla pracownika.

Celem opracowania stało się zatem ukazanie rangi psychospołecznych potrzeb pracowników w kształtowaniu kultury zaangażowania organizacyjnego i wskazanie znaczenia ich uwzględniania w systemie motywacyjnym firmy. Pracownik zaangażowany silniej identyfikuje się z celami i wartościami organizacyjnymi, ma mocne pragnienie przynależności do organizacji, a jednocześnie podejmuje działania wykraczające poza wymagania i standardy [Juchnowicz 2012, s. 7]. Jeśli więc przyjąć, że zaangażowanie stanowi swego rodzaju pochodną możliwości zaspokojenia istotnych potrzeb jednostki, to trzeba stwierdzić, że organizacja prezentująca cele i wartości bliskie osobistym wartościom pracownika, która 
pomaga mu zaspokajać ważne dla niego potrzeby, sprawia, że rośnie jego identyfikacja z firmą i zaangażowanie w realizowane przez nią zadania.

Zaangażowanie pracowników łączy się z ich dobrym samopoczuciem. Zależy to od korzystnej interakcji oczekiwań pracowników z warunkami ich pracy. Pracownik zaangażowany w pracę czerpie przyjemność z wykonywanej pracy i przejawia optymizm wobec stojących przed nim zadań. Przede wszystkim ma poczucie, że w pełni wykorzystuje swój potencjał. Koncentrując się na wykonywanej pracy, „daje więcej z siebie”. Traktuje swoją pracę jako ważny aspekt swojego życia, co sprawia, że traktuje ją poważnie, odnajdując w niej poczucie spełnienia i umocnienia poczucia własnej wartości.

Działanie zaangażowanych pracowników prowadzi do konkretnych rezultatów biznesowych poprzez pełniejsze wykorzystanie posiadanego przez nich potencjału. Pracownik zaangażowany pracuje więcej i intensywniej, osiągając lepsze efekty. Częściej szuka innowacyjnych metod pracy, wytrwale rozwiązuje napotykane problemy, wykracza poza minimum obowiązków, jest zdecydowanie proaktywny i co istotne, wiąże swoją przyszłość z organizacją, w której działa.

\section{Zaangażowanie organizacyjne pracowników w świetle wybranych koncepcji}

Przegląd wybranych prac z dziedziny psychologii pracy i organizacji w zakresie motywacji i zaangażowania pracowników pozwala dostrzec wiele podejść badawczych dotyczących omawianego zagadnienia, a co więcej pozwala niekiedy wskazać na pewne możliwości aplikacyjne w praktyce zarządzania współczesnych polskich organizacji [Foster 2003].

Pierwotnie badania prowadzone na zlecenie pracodawców skupiały się na wykazaniu bezpośredniego przełożenia wzrostu motywacji pracownika na wzrost dochodowości organizacji. Podejście to, wciąż aktualne, wpisuje się wyraźnie w neotaylorowski paradygmat naukowego zarządzania, a zarazem w instrumentalny stosunek do pracowników. Odmienne podejście badawcze nawiązuje do psychologii humanistycznej oraz psychologii pozytywnej. Koncentruje się ono bardziej na jednostce i jej podstawowych psychologicznych potrzebach, podejmując próby określenia przyczyn jej motywacji do pracy. W sposób szczególny skupia się na identyfikacji i charakterystyce pożądanych warunków organizacyjnych, w których pracownik może samorealizować się i rozwijać zawodowo, co wpływa na wysoki poziom odczuwanej przez niego satysfakcji osobistej, a w konsekwencji prowadzi do wyższej efektywności organizacyjnej [Foster 2003, s. 333-355]. 
Powyższe podejście, jak się wydaje, nie jest w Polsce zbyt popularne wśród praktyków zarządzania, którzy oczekują konkretnych algorytmów postępowania w zakresie motywowania, a nie ogólnych wskazówek. Przykładem pewnego algorytmu, na jaki można natrafić w omawianym podejściu, może być koncepcja hierarchii potrzeb A. Maslowa, choć szereg badań wskazuje na jego stosunkowo niski potencjał aplikacyjny (zob. publikacje: V.H. Vrooma, H. Murrella, P.M. Muchinsky'ego za: [Chmiel 2003, s. 336]).

J.R. Hackman i G.R Oldham podkreślają z kolei znaczenie takich aspektów wykonywanej pracy jak: autonomia, różnorodność zadan, tożsamość, ważność i sprzężenie zwrotne. Aspekty te pozytywnie korelują z satysfakcją z pracy, a tym samym wpływają na zaangażowanie pracownika i jego wydajność [Hackman i Oldham 1976, s. 250-279].

Badania empiryczne potwierdzają częściowo przyjęte założenia J.R. Hackmana i G.R Oldhama. Dowodzą one ponadto, że konsekwencje poszczególnych właściwości wykonywanej pracy nie są identyczne [Schultz i Schultz 2002, s. 296-322]. Warto zwrócić uwagę, że badania podejmowane w ramach tego podejścia koncentrują się głównie na właściwościach wykonywanej pracy, a w znacznie mniejszym stopniu na relacjach interpersonalnych i cechach fizycznego środowiska pracy, np. w odróżnieniu od badań F. Herzberga związanych z teorią dwuczynnikową.

F. Herzberg, twórca teorii dwuczynnikowej i koncepcji wzbogacania pracy, wśród czynników motywujących wyróżnił tzw. motywatory, które odpowiadają bezpośrednio za motywację i satysfakcję z pracy oraz czynniki higieny, które mogą powodować niezadowolenie. Motywatory dotyczą wymiarów pracy związanych z charakterem zadań, treścią pracy i odpowiedzialnością, które umożliwiają pracownikowi samorealizację, szacunek i rozwój kariery zawodowej. Czynniki higieny (zewnętrzne wobec pracy) dotyczą właściwości środowiska pracy, hierarchii, relacji z przełożonymi i współpracownikami, polityki i praktyk zarządzania oraz wynagradzania. $Z$ teorii F. Herzberga wynika, że aby podwyższyć poziom zadowolenia pracownika należy wykorzystać właściwe motywatory, co łączy się ze stosowaniem metody wzbogacenia pracy. Warto zwrócić uwagę, że w tle pojawia się, co prawda niewyartykułowana wyraźnie, koncepcja potrzeb, których zaspokojenie w jakimś stopniu obiecują stosowane czynniki motywujące. Współcześnie teoria F. Herzberga podlega krytyce większości psychologów, lecz mimo to programy wzbogacania pracy mogą znaleźć praktyczne zastosowanie [Foster 2003, s. 348-349].

Sposoby wzbogacania pracy polegające na rezygnacji z pewnych form kontroli, na rzecz zwiększania autonomii pracowników bądź na systematycznym sprzężeniu zwrotnym dotyczącym wydajności i jakości pracy oraz na zachęcaniu pracowników do rozwoju, wywierają istotny wpływ na odczuwaną satysfakcję w pracy [Foster 2003, s. 351-352]. W ocenach psychologów pracy i organizacji 
dotyczących praktyki funkcjonowania wielu organizacji podkreśla się jednak obserwowany często, bierny, statyczny charakter satysfakcji i zadowolenia z pracy, ponieważ wielu pracowników dąży przede wszystkim do utrzymania status quo i brakuje w ich pracy aspektów świadczących o dynamice i pasji, charakterystycznych dla zaangażowania [Szabowska-Walaszczyk 2010, s. 147]. Przypuszczalnie łączyć to można z dominacją u tych osób potrzeby bezpieczeństwa, która nie znajduje pełnego zaspokojenia w środowisku pracy i przez to blokuje inne, bardziej pobudzające do aktywności, motywy. Warto zauważyć, że również kultura organizacyjna nie zawsze zawiera cechy sprzyjające stymulowaniu pracowniczych potrzeb psychospołecznych wyższego rzędu.

Inną propozycją, która może być użyteczna do wyjaśniania zachowań opartych na zaangażowaniu, jest teoria autodeterminacji R.M. Ryana i E.L. Deci. Teoria ta bywa między innymi wykorzystywana na gruncie zarządzania kapitałem ludzkim. W podejściu tym, w badaniach nad motywacją wewnętrzną i osobowością, akcentuje się głównie mechanizmy angażowania wewnętrznych zasobów jednostki, które mają decydujące znaczenie dla rozwoju osobowości i autoregulacji zachowań [Ryan i Deci 2000, s. 68-78]. Zdaniem autorów, naturalne dążenie do doskonalenia i rozwoju, które przejawia się w zaspokajaniu potrzeby kompetencji, potrzeby relacji społecznych i potrzeby autonomii jest podstawą optymalnego działania pracownika, w konsekwencji czego odczuwa on wysokie zadowolenie i satysfakcję.

Zaspokojenie tych potrzeb zależy od czynników sytuacyjnych oraz od orientacji celów życiowych (wewnętrznie zorientowane i zewnętrznie zorientowane cele życiowe). Motywacja wewnętrzna jako naturalna tendencja do poszukiwania wyzwań i uczenia się może ulec zakłóceniom poprzez błędne działania menedżerów, którzy nie wspierają jej u pracowników bądź nawet ją tłumią, oraz przez nieadekwatne sprzężenie zwrotne. Badania potwierdzają, że pozytywny feedback zadaniowy wzmacnia motywację wewnętrzną, a narzucone, zewnętrzne ustalanie terminów i sposobu wykonania zadań oraz negatywny feedback, obniża poczucie kontroli i tłumi motywację wewnętrzną. W opinii twórców teorii autodeterminacji stosowanie zewnętrznych nagród organizacyjnych powoduje, że początkowa motywacja wewnętrzna maleje i nabiera charakteru zewnętrznego, stając się coraz bardziej podatna na kontrolę zewnętrzną [Deci 1971, s. 105-115]. W konsekwencji spada wewnętrzne zaangażowanie pracowników.

Teoria autodeterminacji R.M. Ryana i E.L. Deci, opisując zachowania i motywację w kontekście ich użyteczności organizacyjnej, dostarcza menedżerom pewnych praktycznych wskazówek. Wydaje się oczywiste, że w interesie organizacji jest zatrudnianie pracowników kompetentnych i właściwie umotywowanych, ponieważ właśnie tacy pracownicy stanowią cenny kapitał organizacji. Stąd bardzo ważnym działaniem jest prowadzenie rzetelnej i trafnej rekrutacji 
z udziałem psychologów. Możliwa jest wówczas trafna ocena psychospołecznych kompetencji kandydata oraz dokonanie diagnozy rodzaju i poziomu jego motywacji, celem uniknięcia późniejszych, nieefektywnych kontraktów.

W przypadku pracowników o silnej orientacji zewnętrznej i motywacji zewnętrznej stosowanie zewnętrznych nagród i czynników motywacyjnych, takich jak: premie, nagrody organizacyjne, benefity organizacyjne itp., jak się okazuje, może powodować wzrost odczuwanej satysfakcji, lecz mimo to nie powoduje prawdziwego zaangażowania. Korzystnym rozwiązaniem mogłaby być relacja z pracownikiem oparta na indywidualnej transakcji i każdorazowej kalkulacji zysków i strat, jednak w dłuższej perspektywie czasowej stosowanie takiej strategii mogłoby powodować eskalację roszczeń.

Stąd, jak już podkreślano, szczególnie pożądaną grupą pracowników są tacy pracownicy o motywacji wewnętrznej, których osobisty system wartości i celów jest zgodny z celami i wartościami danej organizacji. Ich działanie w dużym stopniu wynikać będzie z zaangażowania. Sporym wyzwaniem dla menedżera jest umiejętne stosowanie zewnętrznych czynników motywacyjnych przy pozostawieniu pracownikom pewnego zakresu swobody decydowania i autonomii, by nie wyeliminować motywacji wewnętrznej stanowiącej podstawę ich zaangażowania. Wyzwaniem największym wydaje się umiejętność przekształcenia motywacji zewnętrznej pracownika w motywację wewnętrzną wynikającą $\mathrm{z}$ powiązania wykonywanych przez niego zadań z realizacją jego głębszych potrzeb i wartości.

Warto zwrócić uwagę, że samo zwiększanie satysfakcji może prowadzić do większego nasycenia lub zaspokojenia podstawowych potrzeb, lecz niekoniecznie do pożądanych działań i wzrostu zaangażowania organizacyjnego. Pracownik może być usatysfakcjonowany wyłącznie tym, że ma na przykład mało wymagającego przełożonego, a przy tym otrzymuje wysokie wynagrodzenie. W takiej sytuacji można przypuszczać, że nie doszło do integracji i powiązania celów i zadań realizowanych przez organizację z wartościami cenionymi przez pracownika, a stosując terminologię A. Maslowa [1990], z potrzebami wyższego rzędu.

Można zatem stwierdzić, że wymienione teorie dostarczają interesującej wiedzy w kontekście kształtowania zaangażowania organizacyjnego i zaangażowania w pracę, lecz wymaga ona kontynuowania badań i dalszych, pogłębionych analiz. Istotną cechą rozważań zaprezentowanych w niniejszym opracowaniu jest teza, zgodnie z którą pojęciem nadrzędnym mogącym łączyć różne podejścia jest pojęcie potrzeb psychospołecznych pracowników. W przekonaniu autorów pojęcie to może mieć również istotne, praktyczne znaczenie, jeśli znajdzie właściwe sobie miejsce w kulturze organizacyjnej danej firmy. 


\section{Kształtowanie kultury zaangażowania organizacyjnego pracowników}

Rozważając problem kształtowania kultury zaangażowania organizacyjnego, należy podkreślić kluczową rolę menedżerów, w tym zwłaszcza działu HR, w inicjowaniu zachowań wpływających pozytywnie na zaangażowanie. Analiza czynników inicjujących zaangażowanie ukazuje istotne znaczenie dostrzegania i rozpoznawania najważniejszych potrzeb pracowników oraz tworzenia warunków umożliwiających bądź ułatwiających ich zaspokajanie. Należy podkreślić, że chodzi zwłaszcza o potrzeby o uniwersalnym charakterze, mające zarazem dla pracownika ważne, osobiste znaczenie. Przydatne może tu być wprowadzone przez M.B. Rosenberga [2003; 2012], rozróżnienie pomiędzy potrzebą a indywidualnymi strategiami jej zaspokajania. Zgodnie z tym rozróżnieniem podstawowe potrzeby mają charakter uniwersalny i dotyczą wspólnych wartości dla ludzkiego gatunku, takich jak np. bezpieczeństwo, akceptacja, autonomia, szacunek, sens, samorealizacja, podczas gdy strategie zaspokajania potrzeb mają charakter wysoce indywidualny i są tak różne, jak różni bywają ludzie. Konflikty dotyczą zazwyczaj strategii, a nie podstawowych potrzeb rozumianych tak, jak to wyżej przedstawiono.

Zestawienie działań umożliwiających kształtowanie zaangażowania w firmie, pozwala dostrzec, że działania te w sposób bardziej lub mniej oczywisty odnoszą się właśnie do podstawowych, uniwersalnych potrzeb człowieka o charakterze psychospołecznym, a mianowicie:

- zatrudnianie pracowników, których wartości osobiste wpisują się w misje, cele i wartości firmy (zapewnianie zgodności pomiędzy wartościami firmy i wartościami - potrzebami pracowników),

- motywujące (nawiązujące do możliwości zaspokojenia istotnych potrzeb) stawianie celów i rozliczanie wyników pracy,

- dopasowanie zakresu obowiązków i struktury zadań do potrzeb, aspiracji i możliwości pracowników,

- angażowanie pracowników w proces podejmowania decyzji poprzez delegowanie uprawnień decyzyjnych i odpowiedzialności (stwarzanie warunków umożliwiających realizację potrzeb autonomii, znaczenia i wywierania wpływu),

- komunikowanie pracownikom znaczenia ich pracy dla efektów zespołu, a tym samym całej organizacji (zaspokajanie potrzeby wywierania wpływu, potrzeby znaczenia, potrzeby sensu),

- przekazywanie konstruktywnych informacji zwrotnych, zarówno pozytywnych, jak i negatywnych (zaspokajanie potrzeby kontroli),

- budowanie odpowiedniej kultury i atmosfery pracy zespołu (tworzenie warunków w celu zaspokajania potrzeby akceptacji i kontaktu emocjonalnego), 
- stwarzanie pracownikom możliwości rozwoju zawodowego wewnątrz organizacji (tworzenie warunków w celu zaspokajania potrzeb samorealizacji),

- wspomaganie pracowników w zachowaniu równowagi pomiędzy życiem zawodowym i prywatnym (tworzenie warunków do zachowania równowagi pomiędzy zaspokajaniem potrzeby osiągnięć oraz potrzeby wypoczynku).

\section{Podsumowanie}

Praca zawodowa należy do tej formy aktywności człowieka, która jest ściśle powiązana $\mathrm{z}$ funkcjonowaniem człowieka w organizacji. Formułując to bardzo ogólnie, można stwierdzić, że zaangażowanie pracownika w dużej mierze zależy od działania systemu motywacyjnego firmy, uwzględniającego oprócz jej interesów indywidualne cechy pracowników, a zwłaszcza ich podstawowe, psychospołeczne potrzeby, funkcjonowanie $\mathrm{w}$ zespole pracowniczym oraz preferencje $\mathrm{w}$ zakresie procesów regulacyjnych.

Współczesne badania z zakresu psychologii pracy i organizacji dostarczają danych, które wskazują, że zaangażowanie organizacyjne jest problemem nader złożonym. Często przyczyną braku zaangażowania bywają przekształcenia organizacyjne lub niestabilna sytuacja rynkowa. Niemniej jednak czynniki psychologiczne, a zwłaszcza potrzeby i to nie tyle potrzeby podstawowe, co tzw. potrzeby wyższego rzędu, okazują się również niezwykle ważne. Dlatego też w kontekście kształtowania kultury zaangażowania organizacyjnego istotną rolę może spełnić uwrażliwienie kadry menedżerskiej na problem psychologicznych źródeł zaangażowania, w tym na znaczenie dostrzegania ważnych dla pracowników potrzeb i wartości oraz sygnalizowania im tego w taki sposób, aby czuli, że są traktowani w sposób osobisty i z należnym szacunkiem, a ich interesy są dostrzegane i brane $\mathrm{w}$ firmie pod uwagę.

\section{Literatura}

Bakker A. [2011], An Evidence-Based Model of Work Engagement, „Current Directions in Psychological Science”, vol. 20(4), http://dx.doi.org/10.1177/0963721411414534.

Chirkowska-Smolak T. [2012], Psychologiczny model zaangażowania $w$ organizacje, Wydawnictwo UAM, Poznań.

Człowiek $w$ pracy $i$ w organizacji. Perspektywa psychologiczna [2011], red. B. Rożnowski, M. Łaguna, Wydawnictwo KUL, Lublin.

Deci E.L. [1971], Effects of Externally Mediated Rewards on Intrinsic Motivation, „,Journal of Personality and Social Psychology", vol. 18, http://dx.doi.org/10.1037/h0030644.

Foster J. [2003], Motywacja w miejscu pracy [w:] Psychologia pracy i organizacji, red. N. Chmiel, GWP, Gdańsk. 
Hackman J.R., Oldham G.R. [1976], Motivation through the Design of Work. Test of a New Theory, „Organizational Behavior and Human Performance”, vol. 16.

Juchnowicz M. [2012], Zaangażowanie pracowników. Sposoby oceny i motywowania, PWE, Warszawa.

Kożusznik B. [2007], Zachowania człowieka w organizacji, PWE, Warszawa.

Maslow A. [1990], Motywacja i osobowość, Pax, Warszawa.

Mastrangelo P.M. [2008], Building High-Performance People and Organization, „The New Employer-Employee Relationship", Praeger, vol. 1.

Psychologia pracy i organizacji [2003], red. N. Chmiel, GWP, Gdańsk.

Rosenberg M.B. [2002], Porozumienie bez przemocy, Santorski \& Co., Warszawa.

Rosenberg M.B. [2012], W świecie porozumienia bez przemocy, MiND, Podkowa Leśna.

Ryan R.M., Deci E.L. [2000], Self- Determination Theory and the Facilitation of Intrisinc Motivation, Social Development and Well-being, „American Psychologist”, vol. 55, nr 1, http://dx.doi.org/10.1037//0003-066x.55.1.68.

Schein E. [1988], Organizational Psychology, Prentica Hall, New York.

Schultz D.P., Schultz S.E. [2002], Psychologia a wyzwania dzisiejszej pracy, Wydawnictwa Naukowe PWN, Warszawa.

Szabowska-Walaszczyk A. [2010], Zaangażowanie w pracy i organizacji [w:] Psychologia zarzqdzania $w$ organizacji, red. A.M. Zawadzka, PWN, Warszawa.

\section{The Culture of Organisational Involvement and the Psychosocial Needs of Employees}

(Abstract)

From a psychological point of view, all human activities are motivated by key needs of the individual, be they biological, economic or psychosocial. As living standards improve, the latter factors become increasingly important. Consequently, successful employee motivation is becoming more and more dependent on complex psychosocial reinforcements.

The authors of this article seek to emphasise the issue of employees' internal motivation, which is often underestimated in practice. In particular, much attention is devoted to the importance of incorporating core psychosocial needs of employees into the company's organisational culture, as the authors believe it to be a key factor contributing to organisational involvement.

Keywords: organisational involvement, organisational culture, psychosocial needs, motivation, management. 